\title{
Joanna Bereżnicka
}

\section{Dopłaty do działalności operacyjnej a stabilność finansowa gospodarstw rolnych w krajach Unii Europejskiej}

Streszczenie: Celem artykułu było rozpoznanie sytuacji ekonomicznej gospodarstw funkcjonujących w krajach Unii Europejskiej z uwzględnieniem dopłat do działalności operacyjnej, a także wskazanie czynników, które oddziaływały na nadwyżkę finansową. Zdolność do wypracowania nadwyżki finansowej uznano za przejaw osiągnięcia stabilności finansowej gospodarstwa. Źródłem danych była baza FADN, a okres badawczy obejmował lata 20092015. Do grupowania państw posłużono się metodą kwartyli, a zmienną, która decydowała o klasyfikacji do odpowiedniego kwartyla, była wielkość ekonomiczna gospodarstw. Do budowy modeli ekonometrycznych wykorzystano modele panelowe z ustalonymi efektami. Z przeprowadzonych badań wynika, że gospodarstwa funkcjonujące w UE były zróżnicowane pod względem wyposażenia w czynniki produkcji, szczególnie ziemię i kapitał, co znalazło odzwierciedlenie w osiąganych wynikach ekonomicznych i finansowych. Dopłaty bezpośrednie stanowiły we wszystkich latach i niemal wszystkich krajach istotny element wpływający na osiągane dochody. Bez dopłat niemal w połowie krajów Unii rolnicy nie byliby w stanie osiągnąć dochodu z działalności rolniczej. Zbudowane modele wskazywały, że na wysokość nadwyżki finansowej oddziałują różne czynniki, w zależności od tego, jakiej wielkości ekonomicznej jest gospodarstwo. Niezależnie jednak od kwartyla destymulantą nadwyżki finansowej były dopłaty bezpośrednie.

Słowa kluczowe: dopłaty, dochód rolniczy, nadwyżka finansowa, stabilność finansowa.

\section{Wprowadzenie}

Rolnictwo odgrywa bardzo ważną rolę w każdej gospodarce, a jak podaje Aldona Mrówczyńska-Kamińska (2008, s. 106) pozostaje ono nadal ważnym sektorem gospodarki narodowej mimo zmniejszenia jego roli w tworzeniu PKB. Potwierdzeniem tego może być chociażby liczba programów kierowanych do tego

Dr inż. Joanna Bereżnicka, Katedra Finansów, Wydział Nauk Ekonomicznych, Szkoła Główna Gospodarstwa Wiejskiego, ORCID 0000-0002-0316-6693, joanna_bereznicka@sggw.pl. 
sektora wspomagających jego trwanie, przetrwanie i rozwój. Najbardziej powszechnym źródłem wsparcia finansowego są dopłaty do działalności operacyjnej. Dopłaty bezpośrednie są transferami środków publicznych, których celem z założenia jest zwiększanie dochodów rolników (Marks-Bielska, Babuchowska 2009, s. 137) w sytuacji niekorzystnej zmiany cen produktów rolnych i które tę rolę spełniają (Poczta 2008, s. 39). Chociaż, jak wynika $z$ badań realizowanych przez Renatę Marks-Bielską i Karolinę Babuchowską (2009, s. 146), rolnicy nie uważają tego źródła za znaczące wsparcie finansowego gospodarstw, a Adam Wąs (2004, s. 26) wskazuje, że pozytywne oddziaływanie tego instrumentu na wzrost dochodów netto ma charakter krótkoterminowy. W związku z tym pojawia się pytanie, czy gospodarstwa funkcjonujące w Unii Europejskiej opierają źródła swoich dochodów rolniczych na wsparciu, czy też mogłyby funkcjonować nawet bez niego. Naturalnym dla każdego biznesu (niezależnie od branży) źródłem korzyści powinny być środki pozyskane z działalności operacyjnej - rolniczej, które są warunkiem przetrwania i rozwoju gospodarstwa rolnego oraz czynnikiem decydującym o bezpieczeństwie finansowym i stabilności finansowej podmiotów funkcjonujących w rolnictwie.

\section{Dopłaty i stabilność finansowa w gospodarstwach rolnych}

Rolnictwo jest w Unii Europejskiej dofinansowywane, subsydiowane. Rola dopłat jest przedmiotem analizy ekonomistów rolnych w dwóch obszarach, tj. z perspektywy oddziaływania wsparcia na dochody rolnicze oraz efektywności gospodarowania w rolnictwie. Rocznie w ramach wspólnej polityki rolnej przeznacza się na sektor rolny około 50 mld euro, a podstawowym celem jest wspieranie dochodów rolników i łagodzenie wpływu produkcji rolnej na środowisko (Rizov, Pokrivcak, Ciaian 2013). Zewnętrzne zasilanie rolnictwa ma istotne znaczenie w kształtowaniu jego sytuacji ekonomiczno-produkcyjnej (Grzelak 2012, s. 104-109).

Teoretyczne badania wskazują, że wsparcie (dotacje) może mieć pozytywny wpływ na produkcję rolniczą, a jednocześnie negatywny na efektywność (produkcyjność) gospodarstw rolnych (Hennessy 1998; Ciaian, Swinnen 2009). Natomiast liczne badania empiryczne nie potwierdzają jednoznaczności tych teoretycznych zależności (np. Zhu, Lansink 2010; Latruffe et al. 2011; Mary 2012). Według Katarzyny Smędzik-Ambroży (2015) po 2009 r. dopłaty bezpośrednie rekompensują utratę korzyści z tytułu ograniczenia intensywności produkcji w gospodarstwach zrównoważonych.

Funkcjonowanie systemu dopłat bezpośrednich pomimo kontrowersji dobrze spełnia swoją funkcję zarówno w zakresie kreowania dochodów rolników, jak i wynagradzania za dostarczanie dóbr publicznych (Czubak, Sadowski, Poczta 2011, s. 60). Jak wynika z badań przeprowadzonych przez Joannę Buks i Roberta 
Pietrzykowskiego (2015, s. 71), dopłaty unijne odegrały kluczową rolę dochodotwórczą w latach 2004, 2006 i 2009. Natomiast w latach 2005 i 2008 złagodziły spadek dochodów w sektorze rolnym. Ponadto zaobserwowano stopniowe zmniejszenie udziału dopłat w dochodzie. Oznacza to, że dopłaty stają się wygasającym czynnikiem egzogennym dynamiki wzrostu dochodu w rolnictwie. Efektem są coraz mniejsze wydatki środków pieniężnych w ramach I filara Wspólnej Polityki Rolnej, a tym samym mniejsze oddziaływanie na kształtowanie dochodów rolniczych, które są ważnym elementem przetrwania gospodarstwa. Do zrealizowania tego celu niezbędna jest stabilność finansowa, gdyż finanse odgrywają istotną rolę w funkcjonowaniu podmiotów gospodarczych.

Pojęcie stabilności finansowej jest definiowane jako stan, w którym system finansowy jako całość nie wykazuje trudności w realizowaniu w sposób trwały płynności lub wypłacalności (Crockett 1997). Przez stabilność finansową rozumie się również brak występowania kryzysów finansowych (Fidrmuc, Schardax 1999). Tak więc stabilność finansowa kojarzy się raczej z systemem finansowym (Zygierewicz 2013, s. 692). Jednak wydaje się, że każdy podmiot, aby mógł bez przeszkód funkcjonować, również musi charakteryzować się stabilnością finansową. Przede wszystkim stabilne finansowo przedsiębiorstwo to takie, które bez zakłóceń jest w stanie realizować cele właścicieli czy interesariuszy. Jest zdolne do wytrzymywania wstrząsów, w sposób trwały nie schodząc z drogi rozwoju. Stabilność finansowa pozwala przedsiębiorstwu na pełne realizowanie funkcji ekonomicznych, związanych z pozyskiwaniem kapitału, dokonywaniem jego podziału i odpowiednim wykorzystaniem w działalności operacyjnej, inwestycyjnej i finansowej. Stabilność finansowa przedsiębiorstwa może być zatem oceniana na podstawie wybranych parametrów finansowych, takich jak płynność, wypłacalność i rentowność (Gorczyńska 2013, s. 105-107). Przedsiębiorstwo powinno mieć możliwość wypracowania norm tych parametrów, by pozwoliły wyznaczyć obszary jego stabilności finansowej. Wykrycie nieprawidłowości w tych obszarach pozwala z kolei na podjęcie odpowiednich działań korygujących bądź też eliminujących ujemne skutki ich wystąpienia. Na osiągnięcie stabilności finansowej wpływa bezpieczeństwo finansowe (Jabłoński 2015, s. 88), dzięki któremu przedsiębiorstwo bez zakłóceń może kontynuować swoją działalność. Jest to możliwe, gdy wygospodarowuje na tyle wysokie nadwyżki pieniężne, by pozwoliły w sposób bezproblemowy funkcjonować w bliżej nieokreślonej przyszłości.

\section{Cel i metodyka badań}

Celem badań było rozpoznanie sytuacji dochodowej i finansowej gospodarstw funkcjonujących w Unii Europejskiej ze szczególnym uwzględnieniem roli dopłat 
do działalności operacyjnej w kształtowaniu stabilności finansowej rozumianej jako zdolności do generowania przez gospodarstw środków pieniężnych oraz zdolności utrzymania przez nie płynności i wypłacalności. Postawiono tezę, że dopłaty w nadmierny sposób wpływają na osiąganie nadwyżki finansowej i pozwalają zyskać stabilność finansową gospodarstwom, którym w sytuacji ich braku mogłaby zagrażać niestabilność.

Do badania zostały wykorzystane dane pochodzące z bazy Farm Accountancy Data Network (FADN), służącej gromadzeniu informacji na potrzeby oceny zjawisk zachodzących w rolnictwie w rajach Unii Europejskiej. Dane dotyczyły wszystkich 28 krajów UE. Okres badań obejmował lata 2009-2015. Ze względu na duże zróżnicowanie siły ekonomicznej (zmienna SE005 w systemie FADN) gospodarstw w poszczególnych krajach wspólnoty zdecydowano się na zastosowanie metody kwartyli do utworzenia jednorodnych grup, które będą podstawą danych do budowy modeli. W pierwszym kwartylu (kraje z gospodarstwami słabymi ekonomicznie) znalazły się: Bułgaria, Grecja, Chorwacja, Litwa, Polska Rumunia, Słowenia, Malta i Portugalia (wielkość standardowej produkcji [SO] wynosiła 33 jednostki). Natomiast w trzecim kwartylu - kraje z gospodarstwami silnymi ekonomicznie były Belgia, Czechy, Dania, Niemcy, Luksemburg, Holandia, Słowacja i Wielka Brytania. Kraje te charakteryzowały się wielkością ekonomiczną o wartości ponad 190 jednostek.

Na potrzeby realizacji postawionych celów w opracowaniu wykorzystano nadwyżkę finansową jako finansowy (pieniężny) efekt prowadzenia gospodarstwa. Stanowiła ona podstawę pomiaru płynności i wypłacalności w ujęciu dynamicznym. Do obliczenia poszczególnych kategorii skorzystano z następujących formuł (1), (2), (3):

$$
\mathrm{NF}=\mathrm{SE} 420-\mathrm{SE} 605+\mathrm{SE} 360
$$

gdzie: NF - nadwyżka finansowa bez dopłat, SE420 - dochód z rodzinnego gospodarstwa rolnego,

SE605 - całkowita wartość dopłat do działalności operacyjnej, SE360 - wartość amortyzacji.

$$
W B P=\frac{N F}{S E 495},
$$

gdzie: WBP - wskaźnik bieżącej płynności,

$\mathrm{NF}-\mathrm{jw}$,

SE495 - wartość zadłużenia krótkoterminowego. 
Dopłaty do działalności operacyjnej a stabilność finansowa gospodarstw rolnych...

$$
W w=\frac{N F}{S E 490+S E 495},
$$

gdzie: $\mathrm{Ww}$ = wskaźnik wypłacalności,

SE490 - wartość zadłużenia długoterminowego, pozostałe jw.

Ilość środków pieniężnych w ten sposób obliczona jest informacją o zdolności przetrwania gospodarstwa. Według Michała Soliwody (2016, s. 104) wskaźnik zadłużenia aktywów może wskazywać na stabilność finansową. Należy zgodzić się z tym poglądem, jednak jedynie z perspektywy zdolności zadłużeniowej gospodarstw, nie zaś zdolności przetrwania gospodarstwa. Autorka artykułu uznała, że nadwyżka finansowa wskazuje na zdolność generowania środków pieniężnych z działalności operacyjnej, a to jest element decydujący o kontynuowaniu działalności przez podmiot gospodarczy (również gospodarstwo).

$\mathrm{Z}$ uwagi na fakt, że w opracowaniu analizowano dane przekrojowo-czasowe, do konstrukcji modeli wykorzystano metody panelowe. Modele te opisują stałą grupę obiektów w więcej niż w jednym okresie. Dzięki informacji o obiektach oraz ich jednoczesnej charakterystyce w poszczególnych okresach modele danych panelowych pozwalają na zredukowanie błędu pomiaru wynikającego z pominięcia ważnych zmiennych nieobserwowalnych dla tych obiektów. Modele te uwzględniają bowiem wpływ na analizowane obiekty dwóch rodzajów czynników (ogólnych i specyficznych). Wyróżnia się dwa rodzaje modeli panelowych: model z efektami stałymi oraz model z efektami losowymi (Korol, Szczuciński 2012, s. 210). W opracowaniu posłużono się modelem z efektami stałymi (fixed effect model), który zakłada, że efekty indywidualne nie są przypadkowe i możliwe jest ich oszacowanie, ponadto mogą wyrażać występowanie pewnych specyficznych cech w regionach. Ogólna formuła modelu jest następująca:

$$
\begin{aligned}
& y_{i t}=X_{i t} \beta+u_{i t} \\
& u_{i t}=\alpha_{i}+\varepsilon_{i t} \\
& y_{i t}=X_{i t} \beta+\alpha_{i}+\varepsilon_{i t},
\end{aligned}
$$

gdzie: $\mathrm{y}$ - zmienna zależna,

$\mathrm{X}_{\mathrm{it}}$ - wektor zmiennych niezależnych obserwowanych dla jednostek i w okresie t, $\mathrm{u}_{\mathrm{it}}$ - błąd zmienności obserwacji specyficznych.

Do obliczeń i budowy modelu posłużono się programem Gretl. Panel nie był w pełni zbilansowany, ponieważ niektóre kraje nie mogły uczestniczyć w badaniu 
w całym okresie (np. informacje gromadzone w FADN dla Chorwacji zaczynają się od 2013 r.), ponadto kraje migrowały między kwartylami, np. Portugalia czy Dania (w 2011 i 2012 r. znalazły się w 2. kwartylu). Zmienną objaśniającą była wielkość nadwyżki finansowej obliczonej według formuły (1).

Ponadto w pracy została wykorzystana analiza opisowa i porównawcza.

\section{Wyniki badań}

Rolnictwo w krajach Unii Europejskiej jest bardzo zróżnicowane, dlatego w tabeli 1 zestawiono podstawowe charakterystyki, które pozwalają na przybliżenie danych informujących o zasobach gospodarstw oraz efektach ekonomicznych, które osiągają rolnicze rodziny prowadzące gospodarstwa rolne. Analizując dane zawarte w tabeli 1, należy stwierdzić, że zasoby pracy wyrażone w jednostkach pełnosprawnych w zdecydowanej większości krajów były zbliżone i wahały się około 1,1-1,56, wyjątek stanowiły gospodarstwa na Malcie (ponad 5 jednostek). Natomiast na Słowacji, w Rumunii, na Węgrzech, w Estonii i Danii zasoby pracy były najniższe spośród badanych krajów i wynosiły poniżej 1 jednostki pełnosprawnej. Dane te świadczą o tym, że na Malcie ponad pięć razy więcej osób jest związanych z pracą we własnym gospodarstwie w porównaniu do innych krajów, gdzie na pełen etat pracuje właściciel $z$ drugą osobą wspierającą, która nie była w pełni zaangażowana $\mathrm{w}$ pracę $\mathrm{w}$ gospodarstwie rolnym. W Polsce liczba pełnosprawnych była nieco wyższa niż dla całej UE, ale jest to wynik bardzo dobry $(1,43)$, który świadczy o tym, że mimo dużej liczby osób zamieszkujących na obszarach wiejskich w rolnictwie pracują na niepełne etaty.

Główny czynnik produkcji w rolnictwie, ziemia, potwierdzał duże zróżnicowanie gospodarstw funkcjonujących w UE. Polska ze średnią powierzchnią około 18,5 ha $^{1}$ zajmowała pod tym względem 8 miejsce od końca w zestawieniu wszystkich państw członkowskich. Największą powierzchnią UR dysponowali rolnicy w Słowacji (ponad 520 ha), natomiast najmniejszą na Malcie - 2,5 ha. Wyposażenie w ziemię prawdopodobnie będzie oddziaływało na osiągane wyniki w związku z wystąpieniem efektu skali. Poza ziemią ważne jest również wyposażenie gospodarstw w aktywa. Jak wynika $\mathrm{z}$ danych zawartych w tabeli 2, wartość majątku w przeliczeniu na 1 ha UR oscylowała około 10 tys. euro, ale najlepiej wyposażone w aktywa były gospodarstwa maltańskie (ponad 70 tys. euro) i holenderskie (ponad 65 tys. euro). Natomiast najsłabiej wyposażone były gospodarstwa

1 Należy pamiętać, że nie jest to średnia wielkość gospodarstwa w Polsce, a powierzchnia gospodarstwa, które uczestniczy w gromadzeniu danych w ramach FADN. Uczestnikami tego systemu gromadzenia danych są gospodarstwa o określonej wielkości produkcji standardowej (gospodarstwa, które produkują na rynek). 


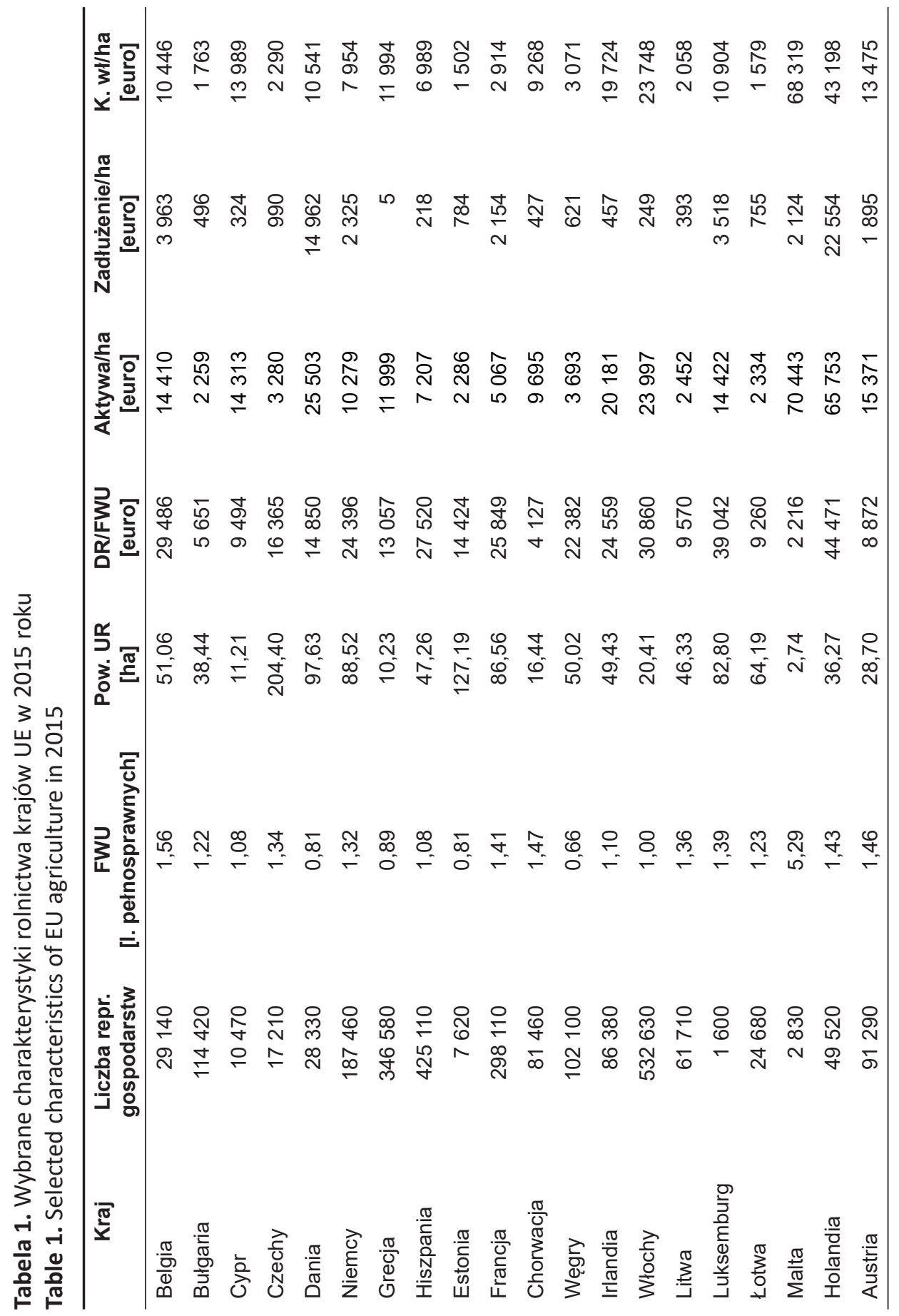




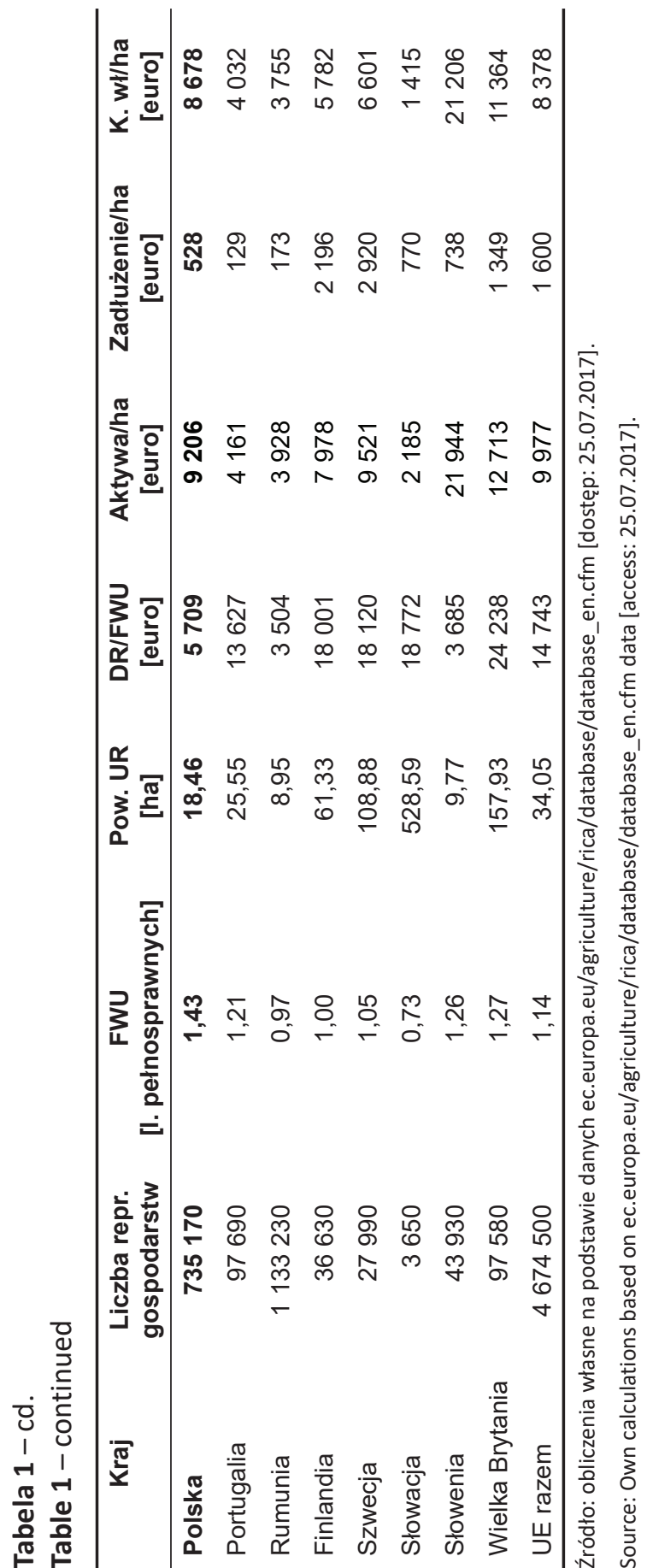


w krajach nadbałtyckich, Słowacji, na Węgrzech oraz w Czechach i była to około 5 razy mniejsza wartość niż przeciętnie dla krajów UE. W polskich gospodarstwach każdy ha UR był wyposażony w majątek o wartości około 9 tys. euro. Oznacza to, że gospodarstwa polskie doinwestowały się w takim stopniu, aby zbliżyć się do średniej UE. Aktywa te były finansowane w bardzo różny sposób w zależności od kraju. Okazuje się, że nie tylko polskie rolnictwo w niewielkim stopniu korzystało $\mathrm{z}$ finansowania zewnętrznego, podobnie $\mathrm{w}$ tym zakresie zachowywali się rolnicy w takich krajach jak Malta, Włochy czy Hiszpania, wykorzystujący głównie własne środki do finansowania zasobów. Z drugiej strony były kraje, w których głównym źródłem finansowania majątku były kapitały obce (np. Dania).

Przywołane informacje mają znaczący wpływ na wysokość przychodów i kosztów, które w sposób jednoznaczny wpływają na dochód. Efekt gospodarowania natomiast, jak twierdzą Walenty Poczta, Joanna Śledzińska i Aldona Mrówczyńska-Kamińska (2009, s. 17), świadczy o istotnej roli wewnętrznego potencjału przedsiębiorstwa, który obejmuje głównie zasoby produkcyjne. Odpowiednio wysoki dochód rolniczy stwarza możliwość poprawy konkurencyjności oraz warunkuje dalszy rozwój (Ryś-Jurek 2009, s. 178), ale także kształtuje bieżącą konsumpcję. W tym kontekście należy zauważyć, że dochód przypadający na jednostkę pełnozatrudnioną w Polsce należał do grupy niższych i wynosił niewiele ponad 5 tys. euro rocznie, a także był przynajmniej kilkakrotnie niższy od średniej dla całej Unii. Oznacza to, że rolnicy w Polsce nadal nie zarabiają wystarczająco dobrze, co jest następstwem niewielkiego wyposażenia w ziemię oraz słabego wyposażenia w majątek - skutkiem jest niższa wydajność. Potwierdzenie tego może stanowić przykład gospodarstw włoskich, które dysponując zbliżonym do polskich warunków areałem i podobnymi zasobami własnej siły roboczej, osiągnęły ponad 6-krotnie wyższe dochody w przeliczeniu na 1 FWU. Należy jednak stwierdzić, że najwyższe dochody w odniesieniu do jednostki pełnozatrudnionej wykazywały gospodarstwa holenderskie i te funkcjonujące w Luksemburgu. Natomiast o tym, jak wysoki był dochód w przeliczeniu na jednostkę powierzchni, informują dane zestawione w tabeli 2.

Analizując dane zestawione w tabeli 2, należy stwierdzić, że efekty ekonomiczne w przeliczeniu na jednostkę powierzchni były bardzo zróżnicowane między poszczególnymi krajami, ale także wykazywały wahania w kolejnych latach (w większości krajów wystąpiła ujemna dynamika zmiany). Wskazuje to na duże wahania dochodów osiąganych w gospodarstwach rolnych. Największe dochody na jednostkę powierzchni wykazywali rolnicy maltańscy z tendencją wzrostową, natomiast najniższe wystąpiły w gospodarstwach rolników słowackich, estońskich, łotewskich i szwedzkich. W przypadku tych ostatnich odnotowano stabilizację dochodu. Dochody w Polsce nie były na imponującym poziomie, ale należy podkreślić, 
Tabela 2. Wysokość dochodu rolniczego w przeliczeniu na ha UR [euro/ha] Table 2. Level of agricultural income per hectare of UAA [Euros/ha]

\begin{tabular}{|c|c|c|c|c|c|c|c|}
\hline \multirow[t]{2}{*}{ Kraj } & \multicolumn{7}{|c|}{ Rok } \\
\hline & 2009 & 2010 & 2011 & 2012 & 2013 & 2014 & 2015 \\
\hline Belgia & 908,5 & 1358,5 & 1075,5 & 1277,7 & 1147,8 & 1028,3 & 902,8 \\
\hline Bułgaria & 141,9 & 237,5 & 224,7 & 236,5 & 214,0 & 216,6 & 241,5 \\
\hline Cypr & 872,2 & 1355,1 & 1477,3 & 1009,4 & 1089,7 & 646,0 & 838,5 \\
\hline Czechy & 51,3 & 104,2 & 223,4 & 227,0 & 237,1 & 276,5 & 194,1 \\
\hline Dania & $-496,4$ & 99,1 & 325,2 & 616,5 & 603,6 & 256,8 & 122,8 \\
\hline Niemcy & 272,0 & 427,7 & 448,5 & 564,7 & 575,7 & 443,9 & 357,7 \\
\hline Grecja & 1597,3 & 1637,2 & 1349,7 & 1188,9 & 1044,5 & 1318,4 & 1132,9 \\
\hline Hiszpania & 556,6 & 615,8 & 601,3 & 534,4 & 543,3 & 507,9 & 651,4 \\
\hline Estonia & 82,9 & 150,3 & 182,2 & 200,2 & 124,8 & 59,0 & 88,3 \\
\hline Francja & 211,8 & 501,8 & 538,5 & 557,2 & 365,3 & 385,7 & 420,0 \\
\hline Chorwacja & bd. & bd. & bd. & bd. & 340,4 & 427,4 & 440,6 \\
\hline Węgry & 138,4 & 256,3 & 411,3 & 399,3 & 375,5 & 436,0 & 321,0 \\
\hline Irlandia & 366,3 & 392,9 & 552,2 & 447,9 & 437,3 & 531,7 & 545,0 \\
\hline Włochy & 1379,4 & 1446,4 & 1428,9 & 1468,5 & 1346,3 & 1635,0 & 1513,5 \\
\hline Litwa & 280,6 & 321,9 & 336,2 & 346,6 & 265,8 & 192,1 & 292,6 \\
\hline Luksemburg & 322,1 & 340,2 & 644,2 & 482,0 & 563,7 & 771,8 & 653,2 \\
\hline Łotwa & 107,8 & 149,1 & 178,3 & 190,5 & 139,7 & 154,8 & 214,3 \\
\hline Malta & 2519,9 & 3545,8 & 2817,9 & 3534,6 & 4263,4 & 4174,5 & 4323,4 \\
\hline Holandia & 644,9 & 1651,0 & 1106,4 & 1831,8 & 1944,0 & 1431,5 & 1754,5 \\
\hline Austria & 696,1 & 752,0 & 978,1 & 900,2 & 765,8 & 534,8 & 450,2 \\
\hline Polska & 349,9 & 540,3 & 584,4 & 582,4 & 524,6 & 477,8 & 441,7 \\
\hline Portugalia & 441,5 & 516,9 & 499,3 & 510,4 & 524,6 & 500,4 & 646,0 \\
\hline Rumunia & 363,0 & 476,1 & 565,0 & 564,5 & 596,0 & 539,7 & 396,4 \\
\hline Finlandia & 287,1 & 436,6 & 399,5 & 378,7 & 293,8 & 357,0 & 292,8 \\
\hline Szwecja & 56,3 & 170,3 & 171,5 & 156,4 & 169,7 & 22,1 & 174,0 \\
\hline Słowacja & $-171,9$ & $-86,8$ & 27,5 & $-14,2$ & $-10,5$ & 24,8 & $-19,9$ \\
\hline Słowenia & 655,4 & 612,3 & 630,5 & 458,5 & 468,9 & 464,3 & 473,4 \\
\hline Wielka Brytania & 254,2 & 333,6 & 397,4 & 308,7 & 266,9 & 303,4 & 195,9 \\
\hline Cała UE & 408,5 & 558,7 & 588,5 & 588,3 & 533,6 & 521,1 & 503,4 \\
\hline
\end{tabular}

Źródło: obliczenia własne na podstawie danych ec.europa.eu/agriculture/rica/database/database_en.cfm [dostęp: 25.07.2017].

Source: Own calculations based on ec.europa.eu/agriculture/rica/database/database_en.cfm data [access: 25.07.2017]. 
że zbliżały się do tych wykazywanych przez rolników z Hiszpanii, Portugalii, Irlandii i Niemiec. Może to być dobry sygnał dla polskich użytkowników gospodarstw z tego względu, że osiągnęli efekty zbliżone do kraju, w którym powierzchnia gospodarstwa była 4 razy większa. Oznacza to, że sytuację dochodową polskich gospodarstw można określić jako przeciętną. Należy jednoznacznie stwierdzić, że od 2011 r. wystąpiła tendencja spadkowa dochodów, chociaż to zjawisko było powszechnie zauważalne w krajach UE. Największe spadki wystąpiły w Danii i Rumunii, ale także w Wielkiej Brytanii. Na tę sytuację wpływ miały bardzo różne czynniki, a jednym z nich mogła być zmiana w zakresie przyznawania wsparcia do działalności operacyjnej. W tabeli 3 zestawiono wartość dopłat do działalności operacyjnej w przeliczeniu na 1 ha UR.

Tabela 3. Wartość dopłat do działalności operacyjnej w przeliczeniu na 1 ha [euro] Table 3. Amount of operating subsidies per hectare [Euros]

\begin{tabular}{lccccccc}
\hline \multicolumn{1}{c}{ Kraj } & \multicolumn{7}{c}{ Rok } \\
\cline { 2 - 7 } & $\mathbf{2 0 0 9}$ & $\mathbf{2 0 1 0}$ & $\mathbf{2 0 1 1}$ & $\mathbf{2 0 1 2}$ & $\mathbf{2 0 1 3}$ & $\mathbf{2 0 1 4}$ & $\mathbf{2 0 1 5}$ \\
\hline Belgia & 525,4 & 535,5 & 518,5 & 508,1 & 501,9 & 495,0 & 437,7 \\
Bułgaria & 186,2 & 185,8 & 160,7 & 185,3 & 263,5 & 237,7 & 271,4 \\
Cypr & 486,9 & 462,0 & 457,2 & 549,8 & 543,4 & 430,1 & 485,9 \\
Czechy & 337,7 & 343,7 & 356,0 & 367,3 & 412,2 & 413,7 & 410,7 \\
Dania & 403,0 & 386,4 & 383,8 & 383,0 & 374,4 & 364,7 & 356,6 \\
Niemcy & 421,6 & 426,2 & 422,3 & 407,7 & 399,4 & 408,8 & 399,6 \\
Grecja & 841,5 & 823,0 & 757,2 & 708,2 & 675,9 & 651,0 & 583,6 \\
Hiszpania & 254,2 & 282,5 & 271,0 & 243,1 & 234,9 & 252,4 & 241,5 \\
Estonia & 153,5 & 192,9 & 196,4 & 195,3 & 197,4 & 182,8 & 189,6 \\
Francja & 356,5 & 362,6 & 358,6 & 358,6 & 346,9 & 337,0 & 337,7 \\
Chorwacja & bd. & bd. & bd. & bd. & 274,6 & 345,2 & 324,5 \\
Węgry & 254,5 & 284,9 & 334,4 & 326,6 & 355,0 & 351,3 & 319,7 \\
Irlandia & 437,0 & 440,3 & 439,5 & 429,9 & 402,8 & 383,8 & 354,6 \\
Włochy & 365,6 & 389,5 & 398,8 & 413,7 & 411,3 & 422,5 & 412,5 \\
Litwa & 183,5 & 185,5 & 173,7 & 179,9 & 196,9 & 193,6 & 210,8 \\
Luksemburg & 534,2 & 540,9 & 654,9 & 612,3 & 566,7 & 562,6 & 704,1 \\
Łotwa & 206,2 & 201,1 & 186,2 & 190,1 & 195,9 & 222,3 & 231,4 \\
Malta & 1175,2 & 1390,8 & 1054,4 & 1149,6 & 1117,9 & 1034,9 & 923,0 \\
Holandia & 531,1 & 548,9 & 576,9 & 599,7 & 499,8 & 442,7 & 537,1 \\
Austria & 636,1 & 591,5 & 596,5 & 588,0 & 566,5 & 613,4 & 569,5 \\
\hline
\end{tabular}


Tabela 3 - cd.

Table 3 - continued

\begin{tabular}{llllllll}
\hline \multirow{2}{*}{ Kraj } & \multicolumn{7}{c}{ Rok } \\
\cline { 2 - 8 } & $\mathbf{2 0 0 9}$ & $\mathbf{2 0 1 0}$ & $\mathbf{2 0 1 1}$ & $\mathbf{2 0 1 2}$ & $\mathbf{2 0 1 3}$ & $\mathbf{2 0 1 4}$ & $\mathbf{2 0 1 5}$ \\
\hline Polska & 280,3 & 310,9 & 316,3 & 298,9 & 317,0 & 316,1 & 278,2 \\
Portugalia & 251,6 & 272,2 & 256,6 & 276,4 & 279,5 & 264,8 & 370,8 \\
Rumunia & 172,8 & 149,8 & 166,0 & 192,9 & 205,0 & 158,8 & 101,9 \\
Finlandia & 901,4 & 920,6 & 913,1 & 897,3 & 870,7 & 882,7 & 841,9 \\
Szwecja & 348,7 & 375,4 & 403,1 & 380,7 & 389,7 & 376,5 & 398,8 \\
Słowacja & 321,8 & 301,0 & 286,3 & 270,8 & 273,7 & 297,3 & 287,7 \\
Słowenia & 724,6 & 708,9 & 616,5 & 635,2 & 714,4 & 671,3 & 600,7 \\
Wielka & & & & & & & \\
Brytania & 275,0 & 273,4 & 267,9 & 259,0 & 247,8 & 244,4 & 237,1 \\
Cała UE & 337,8 & 346,5 & 346,2 & 337,9 & 336,4 & 333,4 & 324,7 \\
\hline
\end{tabular}

Źródło: obliczenia własne na podstawie danych ec.europa.eu/agriculture/rica/database/database_en.cfm [dostęp: 25.07.2017].

Source: Own calculations based on ec.europa.eu/agriculture/rica/database/database_en.cfm [access: 25.07.2017].

Wartość dopłat była zróżnicowana w przeliczeniu na jednostkę powierzchni i wykazywała tendencję malejącą. Należy zauważyć, że polskie gospodarstwa otrzymywały dopłaty w wysokości 279-316 euro i była to wartość porównywalna z wysokością dopłat otrzymywanych przez rolników hiszpańskich, portugalskich, słowackich, angielskich i bułgarskich (w ostatnich dwóch latach) oraz zbliżona do wartości średniej dla całej Unii. Niższe wsparcie związane z działalnością operacyjną otrzymywali natomiast rolnicy z krajów nadbałtyckich oraz Rumunii, przekraczało ono 200 euro/ha. Natomiast najwyższe wsparcie otrzymywały (i wydaje się, że to nie ulegnie zmianie w przyszłości) gospodarstwa z Malty, Finlandii, Słowenii, Austrii, Holandii oraz Luksemburga. Interesująco wygląda również sytuacja Grecji, w przypadku której dopłaty do działalności operacyjnej na jednostkę powierzchni były bardzo wysokie, ale jednocześnie w badanym okresie wykazywały spadek o $30 \%$, z poziomu ponad 800 euro do niewiele ponad 500 euro/ha. Była to konsekwencja problemów finansowych Grecji i wprowadzenia programu oszczędnościowego. Miało to przełożenie na tendencje w wysokości dochodu (tab. 2), podobne zależności zaobserwować można także w przypadku Danii. Należy zwrócić uwagę również na sytuację Finlandii, w przypadku której dochód na jednostkę powierzchni był niemal identyczny jak wartość dopłat, podobnie w Szwecji. Wskazuje to na brak zdolności osiągania dochodu ze sprzedaży produkcji rolnej. Zestawiając dane 
z tabel 2 i 3, należy stwierdzić, że dochody generowane są dopłatami do działalności operacyjnej. Dzięki dopłatom rolnictwo jest bardziej atrakcyjną formą działalności. Niestety dopłaty wspomagają stabilność finansową gospodarstw, a rolnicy utrzymują swój biznes dzięki transferom budżetowym. Nie dotyczy to wszystkich krajów.

Należy zwrócić jednak uwagę na takie kraje, jak: Finlandia, Szwecja, Czechy, Estonia i Dania. Sytuacja w nich wskazywała na uzyskiwanie dopłat co najmniej równych, a nawet przekraczających wartość uzyskiwanych dochodów z działalności rolniczej, czyli de facto rolnicy, gdyby nie dopłaty, ponosiliby straty, prowadząc gospodarstwa.

Wartość kreowanego dochodu była w takim samym stopniu wynikiem dopłat i działalności operacyjnej m.in. w Irlandii, Luksemburgu, na Łotwie, w Słowenii, Wielkiej Brytanii i Niemczech. W polskich gospodarstwach dopłaty stanowiły ponad $60 \%$ wartości wykazanego dochodu $\mathrm{z}$ rodzinnego gospodarstwa rolnego i udział ten zmniejszał się. W podobnej sytuacji byli rolnicy greccy, belgijscy, portugalscy oraz prowadzący gospodarstwa na Cyprze. Można w przypadku tych gospodarstw stwierdzić, że rolnicy potrafili osiągać dochody wyższe niż oferowane im wsparcie finansowe. Najlepszą sytuację (najniższa wartość dopłat w relacji do dochodu) wykazywały gospodarstwa rolników włoskich, holenderskich, rumuńskich oraz na Malcie. Wskazuje to na dość efektywnie funkcjonujące rolnictwo, szczególnie w tym ostatnim wymienionym kraju, gdzie wartość dopłat na 1 ha była najniższa (tab. 3). Natomiast należy stwierdzić, że rolnicy z Finlandii osiągali dochód jedynie dzięki dopłatom, otrzymując do 1 ha ponad 800 euro (tab. 3). Bardzo interesujący jest przypadek gospodarstw słowackich, które mimo dopłat na poziomie zbliżonym do polskich nie wygospodarowały dodatniego wyniku z działalności operacyjnej (jest to nadal konsekwencja zmian społeczno-kulturowych $\mathrm{z}$ okresu po przekształceniach prowadzonych po okresie kolektywizacji (Slavkovský 2005, s. 121-131).

Oparcie dochodów na wsparciu wskazuje na ograniczanie efektywności i należy zgodzić się z Wojciechem Jóźwiakiem i Zofią Mirkowską (2008), że dopłaty ograniczają zainteresowanie rolników wzrostem efektywności gospodarowania. Można to stwierdzenie odnoszące się do polskich rolników zastosować do tych prowadzących gospodarstwa w innych krajach. Gdyby wyeliminować dopłaty z dochodu, należałoby stwierdzić, że działalność rolnicza okazała się najbardziej dochodowa ( $\mathrm{z}$ tendencją wzrostową) w gospodarstwach maltańskich - nastąpił ponad dwukrotny wzrost w ciągu 7 lat, holenderskich oraz włoskich. W gospodarstwach rolników belgijskich i cypryjskich, a także greckich wystąpiłby dość wysoki dochód w przeliczeniu na jednostkę powierzchni, ale wykazywał tendencję spadkową, bardzo silną na Cyprze. W gospodarstwach polskich osiągany dochód kształtowałby się w granicach około 200 euro na ha i niestety także wykazywał 
tendencję spadkową. Najgorsza sytuacja wystąpiłaby w gospodarstwach rolników fińskich, szwedzkich, słowackich, słoweńskich i czeskich. We wszystkich badanych latach rolnicy $\mathrm{z}$ tych krajów mogli funkcjonować jedynie dzięki dopłatom i tylko dzięki temu wsparciu wykazywali dochód (wyjątek stanowi Słowacja, w której mimo dopłat przedsiębiorstwa rolne przynosiły straty). Na tym tle interesująco wygląda sytuacja rolników rumuńskich, którzy byli w stanie osiągnąć dochód (wyższy od tego w polskich gospodarstwach), gospodarując na niewiele ponad 8 ha powierzchni użytków rolnych. Wskazuje to na dość dużą wydajność osiąganą w tych gospodarstwach.

Dochód, mimo że jest uznawany za najbardziej syntetyczny miernik sytuacji życiowej ludności (Zawojska 1997, s. 110), nie jest nośnikiem pełnej informacji o tym, jaką wartością środków pieniężnych dysponują prowadzący gospodarstwo rolne. Nośnikiem takiej informacji może być nadwyżka finansowa. Na rysunku 1 zestawiono dane dotyczące wartości nadwyżki finansowej w przeliczeniu na jednostkę powierzchni UR w ujęciu bez uwzględniania dopłat.

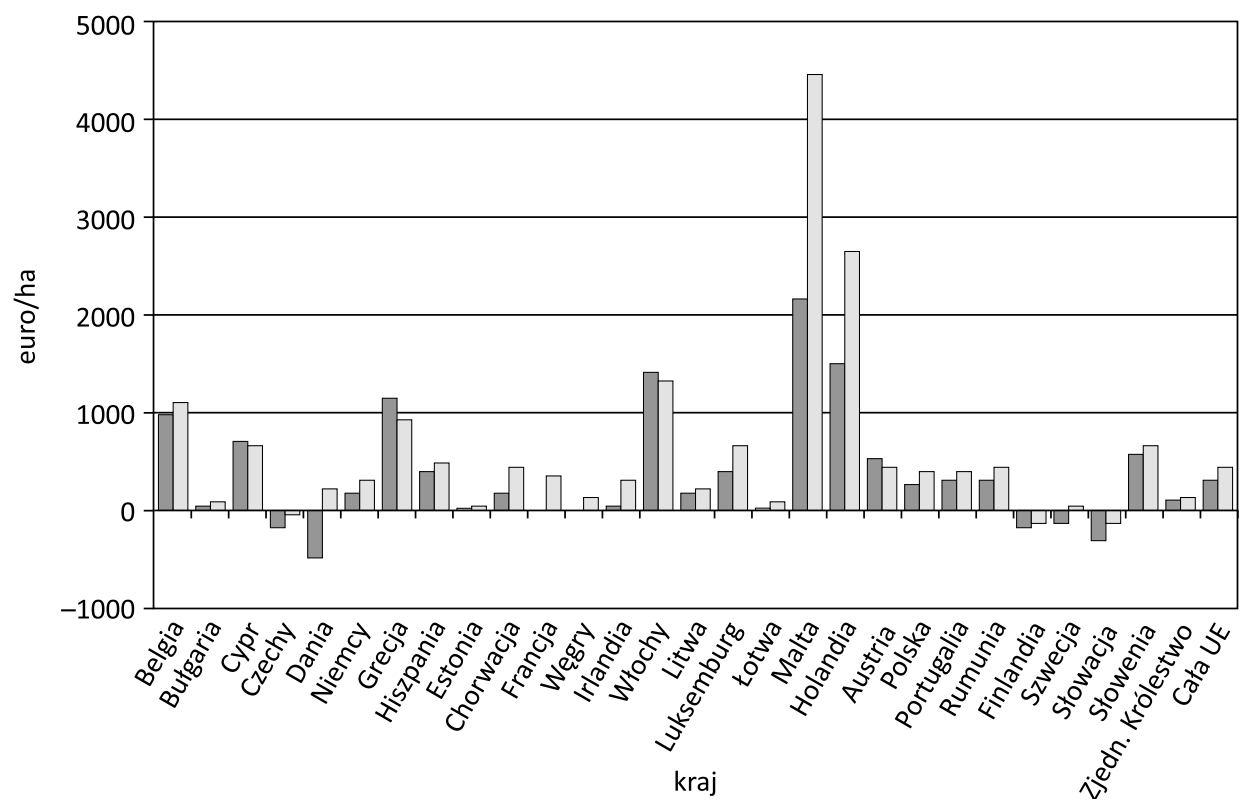

Rysunek 1. Wartość nadwyżki finansowej na ha UR [euro/ha]

Figure 1. Value of financial surplus per hectare of UAA [Euros/ha]

Źródło: obliczenia własne na podstawie danych ec.europa.eu/agriculture/rica/database/database_en.cfm [dostęp: 25.07.2017].

Source: Own calculations based on ec.europa.eu/agriculture/rica/database/database_en.cfm [access: 25.07.2017]. 
Dane przedstawione na rysunku 1 wykazywały wyższe wartości niż wielkości dochodu rolniczego (por. tab. 2) - jest to oczywiście spowodowane uwzględnieniem amortyzacji. Największe różnice między dochodem a nadwyżką wystąpiły na Malcie i w Holandii. W pozostałych krajach rolnicy mieli do dyspozycji środki pieniężne $\mathrm{z}$ amortyzacji. Jednak wykorzystanie amortyzacji do „konsumpcji” prowadzi do dekapitalizacji zasobów, co może mieć negatywne skutki w przyszłości, szczególnie w zakresie wzrostu konkurencyjności gospodarstw na globalnym rynku. Informacja o wysokości wygospodarowanych środków pieniężnych nie jest wystarczająca z perspektywy korzystania z zewnętrznych źródeł finansowania, dlatego w tabeli 4 zestawiono wielkość wskaźnika płynności bieżącej (WBP) oraz wskaźnika wypłacalności (Ww) w badanych latach.

Wskaźniki płynności dla całej Unii kształtowały się na poziomie uważanym $\mathrm{w}$ literaturze $\mathrm{z}$ zakresu analizy finansowej na odpowiednim poziomie, czyli wygospodarowana nadwyżka finansowa równoważyła poziom zadłużenia. Jednak w 12 krajach stabilność finansowa mogłaby zostać zachwiana w sytuacji braku dopłat, można do nich zaliczyć Finlandię, Słowację, Czechy, gdzie rolnicy nie osiągnęli dodatnich przepływów pieniężnych $\mathrm{z}$ działalności operacyjnej. Jest to zjawisko niepokojące z perspektywy przetrwania gospodarstwa, w tych przypadkach nieocenioną rolę odgrywa wsparcie finansowe. Dość niepokojąco wyglądała również sytuacja w Bułgarii, Danii, Niemczech, Estonii, we Francji, na Węgrzech, Łotwie i w Wielkiej Brytanii. Co prawda rolnicy w tych krajach wygospodarowali nadwyżkę finansową, lecz jej poziom był niewielki i wystarczał na pokrycie do $60 \%$ zobowiązań bieżących. W przypadku tych krajów również mogło wystąpić zagrożenie utraty stabilności finansowej. Z kolei w takich krajach jak Belgia, Cypr, Grecja czy Włochy wysokość wygospodarowanych środków pieniężnych z działalności rolniczej była na tyle wysoka, a zadłużenie krótkoterminowe tak niskie, że nie było zagrożenia utratą zdolności płatniczej rolników.

Oceniając wypłacalność, należy stwierdzić, że lista krajów, w których rolnicy wygospodarowali środki pieniężne z działalności operacyjnej w wielkości do $60 \%$ wartości zadłużenia, wydłużyła się. Oczywiście w długiej perspektywie zjawisko mogłoby być niepokojące, ale ze względu na powszechną pomoc kierowaną do rolnictwa gospodarstwom nie grozi utrata stabilności finansowej. Polskie rolnictwo na tle krajów UE charakteryzuje dość stabilna sytuacja finansowa, spowodowane jest to racjonalnym poziomem zadłużenia oraz niewielkimi, ale dodatnimi przepływami pieniężnymi, które rolnicy wypracowują z działalności operacyjnej. 


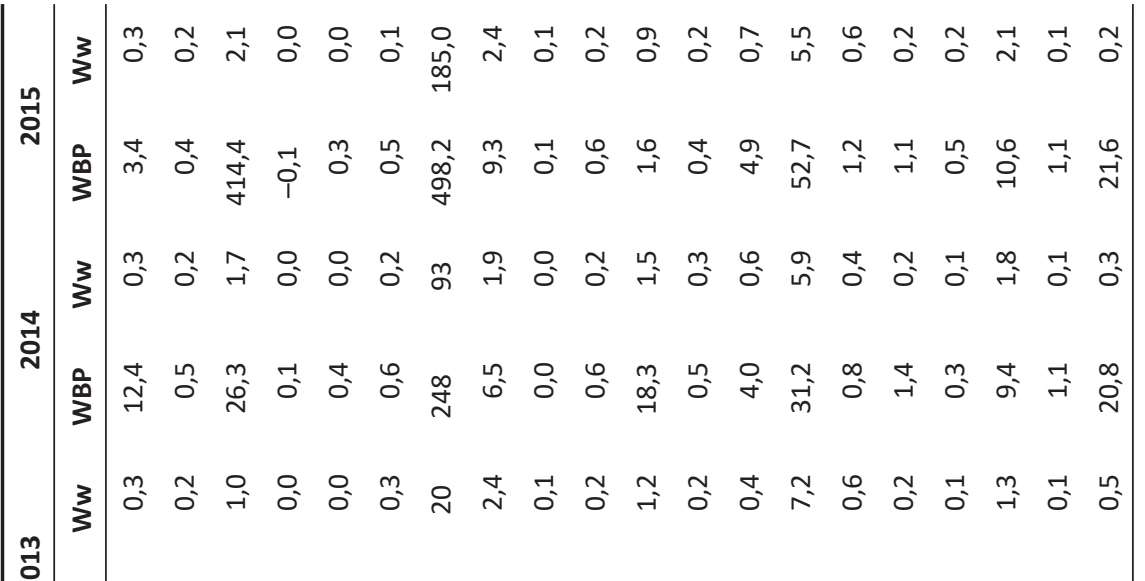

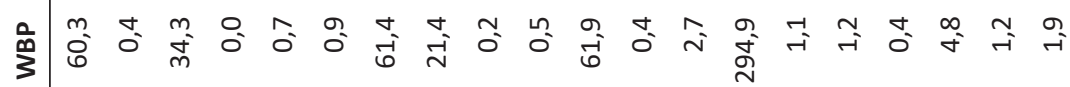

3ँ

공

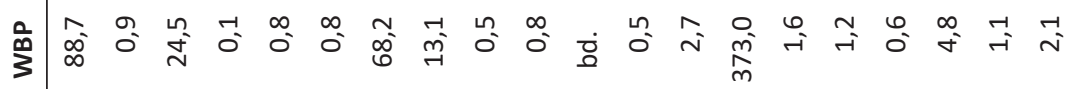

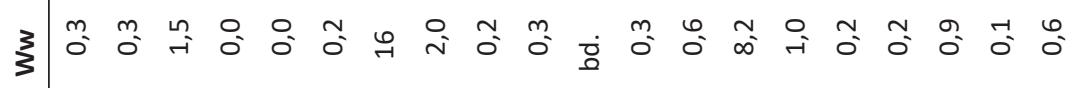

ন্ড

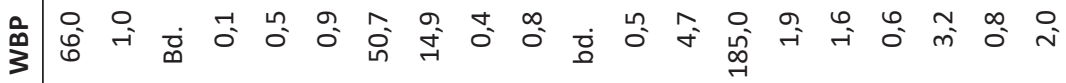

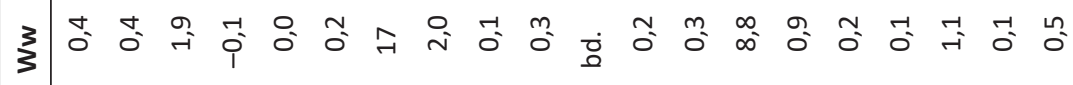

웅

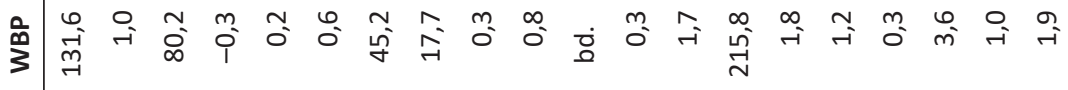

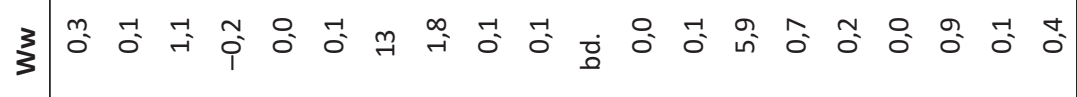

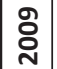

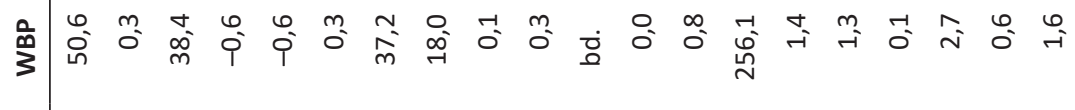

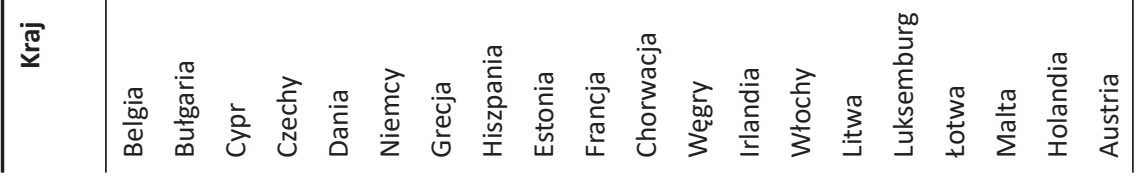




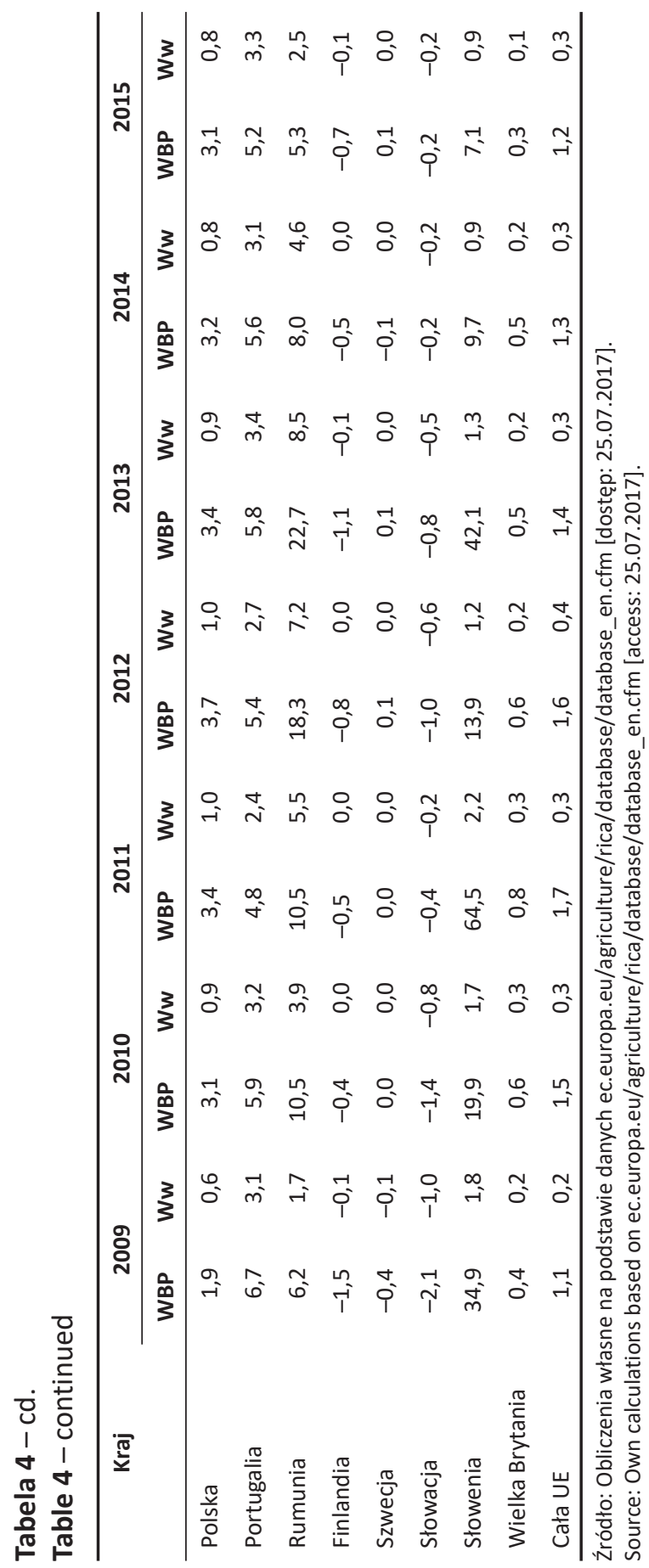




\section{Czynniki determinujące stabilność finansową - rozwiązania modelowe}

Przeprowadzone wcześniej badania wskazywały na wystąpienie zagrożenia kreowania nadwyżki finansowej (przepływów z działalności operacyjnej), które prowadzić może do utraty stabilności finansowej w niektórych krajach, w sytuacji gdyby wycofano wsparcie dla rolników w postaci dopłat do działalności operacyjnej. Dla zbadania czynników oddziałujących na możliwość generowania przez gospodarstwa środków pieniężnych z działalności operacyjnej zostały zbudowane modele, w których estymacja odbywała się z wykorzystaniem ustalonych efektów. Modele stworzono dla kwartyla 3 i kwartyla 1, a zmienną objaśnianą była nadwyżka finansowa bez dopłat (NF bez SE605). Otrzymane rezultaty zestawiono w tabelach 5 i 6.

Tabela 5. Model - Ustalone efekty, zmienna zależna (Y): NF bez SE605, odporne błędy standardowe (robust HAC), kwartyl 3

Table 5. Model - estimation of fixed effects, dependent variable (Y): NF bez SE605, resistant standard errors (robust HAC), quartile 3

\begin{tabular}{lccccc}
\hline \multicolumn{1}{c}{ Zmienna objaśniająca } & Współczynnik & Błąd stand. & t-Studenta & wartość p & Istot. \\
\hline Const & $-2828,07$ & 53462,2 & $-0,0529$ & 0,95812 & \\
$\begin{array}{l}\text { Produktywność ziemi } \\
\text { (SE131/SE025) }\end{array}$ & 42,146700 & 10,305600 & 4,0897 & 0,00025 & $* * *$ \\
$\begin{array}{l}\text { Dopłaty do dz. operacyjnej } \\
\text { (SE605) }\end{array}$ & $-0,803058$ & 0,118101 & $-6,7997$ & $<0,00001$ & $* * *$ \\
$\begin{array}{l}\text { Zadłużenie } \\
\text { krótkoterminowe (SE495) }\end{array}$ & 0,164524 & 0,029856 & 5,5107 & $<0,00001$ & $* * *$ \\
$\begin{array}{l}\text { Zadłużenie } \\
\text { długoterminowe (SE490) }\end{array}$ & $-0,497748$ & 0,148381 & $-3,3545$ & 0,00196 & $* * *$ \\
Aktywa obrotowe (SE465) & 0,350940 & 0,066224 & 5,2993 & $<0,00001$ & $* * *$ \\
\hline Średn. aryt. zm. zależnej & 24446,80 & Odch. stand. zm. zależnej & 54924,52 \\
Suma kwadratów reszt & $5,00 e+09$ & Błąd standardowy reszt & & 12126,13 \\
Wsp. determ. R-kwadrat & 0,967 & Skorygowany R-kwadrat & & 0,95 \\
F(16, 34) & 61,98 & Wartość p dla testu F & & $1,95 e-20$ \\
Logarytm wiarygodności & $-541,58$ & Kryt. inform. Akaike’a & & 1117,17 \\
Kryt. bayes. Schwarza & 1150,01 & Kryt. Hannana-Quinna & & 1129,72 \\
Autokorel. reszt - rho1 & 0,11 & Stat. Durbina-Watsona & & 1,23 \\
\hline
\end{tabular}

Test na normalność rozkładu reszt - Hipoteza zerowa: składnik losowy ma rozkład normalny; statystyka testu: Chi-kwadrat(2) =6,83653, z wartością $\mathrm{p}=0,0327693$.

Źródło: obliczenia własne z wykorzystaniem programu Gretl.

Source: Own calculations by using Gretl software. 
Dopłaty do działalności operacyjnej a stabilność finansowa gospodarstw rolnych...

Tabela 6. Model - estymacja ustalone efekty, zmienna zależna (Y): NF bez SE605, odporne błędy standardowe (robust HAC), kwartyl 1

Table 6. Model - estimation of fixed effects, dependent variable (Y): NF bez SE605, resistant standard errors (robust $\mathrm{HAC}$ ), quartile 1

\begin{tabular}{lccccc}
\hline \multicolumn{1}{c}{ Zmienna niezależna } & Współczynnik & Błąd stand. & t-Studenta & Wartość p & Istot. \\
\hline const & $-1977,27$ & 1927,56 & $-1,0258$ & 0,31268 & \\
$\begin{array}{l}\text { Dopłaty do dz. operacyjnej } \\
\text { (SE605) }\end{array}$ & $-0,568069$ & 0,178433 & $-3,1837$ & 0,00323 & $* * *$ \\
$\begin{array}{l}\text { Dochód na jed. pełnosprawną } \\
\text { (SE430) }\end{array}$ & 0,996615 & 0,174296 & 5,7179 & $<0,00001$ & $* * *$ \\
Aktywa obrotowe (SE465) & 0,154356 & 0,065979 & 2,3395 & 0,02571 & $* *$ \\
Kapitał własny (SE501) & 0,030446 & 0,015072 & 2,0200 & 0,05182 & $*$ \\
\hline Średn. aryt. zm. zależnej & 7438,72 & Odch. stand. zm. zależnej & 2758,78 \\
Suma kwadratów reszt & 18001926 & Błąd standardowy reszt & 750,04 \\
Wsp. determ. R-kwadrat & 0,949 & Skorygowany R-kwadrat & 0,926 \\
F(15, 32) & 40,25 & Wartość p dla testu F & $1,69 \mathrm{e}-16$ \\
Logarytm wiarygodności & $-376,14$ & Kryt. inform. Akaike’a & 784,28 \\
Kryt. bayes. Schwarza & 814,22 & Kryt. Hannana-Quinna & & 795,60 \\
Autokorel. reszt - rho1 & 0,31 & Stat. Durbina-Watsona & 0,85 \\
\hline
\end{tabular}

Test na normalność rozkładu reszt - Hipoteza zerowa: składnik losowy ma rozkład normalny. Statystyka testu: Chi-kwadrat(2) = 7,57294 z wartością $\mathrm{p}=0,0226755$.

Źródło: obliczenia własne z wykorzystaniem programu Gretl.

Source: Own calculations by using Gretl software.

Zmienne objaśniające w obu modelach były inne, co wynika $\mathrm{z}$ różnic $\mathrm{w}$ sposobie gospodarowania silnych i słabych ekonomicznie gospodarstw, np. w zakresie chociażby korzystania z zewnętrznych źródeł finansowania. I tak dla gospodarstw silnych ekonomicznie (kwartyl 3) stymulantami zmiennej objaśnianej była w największym stopniu produkcyjność ziemi, której zmiana przyczyniała się do bardzo dużej poprawy wartości nadwyżki finansowej, kolejnymi stymulantami (ale z mniejszą siłą oddziaływania) były wartość aktywów obrotowych oraz zadłużenie krótkoterminowe (prawdopodobnie były to zobowiązania, które nie pociągały dodatkowych kosztów). Natomiast wśród destymulant wystąpiły zewnętrzne źródła finansowania, przy czym destymulantą wpływającą z większą siłą na zmienną zależną były dopłaty bezpośrednie. Oznacza to, że zwiększenie dopłat do działalności operacyjnej może niekorzystnie wpływać na wysokość nadwyżki finansowej wygospodarowanej z podstawowej działalności gospodarstw. 
Analizując dane zestawione w tabeli 6, można zaobserwować, że najistotniejszą zmienną objaśniającą była wielkość dochodu przypadającego na jednostkę pełnozatrudnioną oraz aktywa obrotowe. Te ostatnie wykazywały mniejszą siłę oddziaływania i mniejszą istotność. Ważny (statystycznie istotny na poziomie $\mathrm{p}=$ 0,05 ) był również kapitał własny, ale to nie dziwi, ponieważ kapitał własny był dominującym źródłem finansowania gospodarstw słabszych ekonomicznie. Natomiast w przypadku tej grupy gospodarstw i krajów dopłaty do działalności operacyjnej także były destymulantą i w dosyć dużym stopniu negatywnie oddziaływały na nadwyżkę finansową wypracowywaną $\mathrm{w}$ ramach działalności rolniczej.

Zaproponowane zestawy zmiennych objaśniających pozwalały na wyjaśnienie zmienności nadwyżki finansowej w ponad 90\%, co jest wynikiem bardzo dobrym.

\section{Podsumowanie}

Przeprowadzone badania potwierdziły, że sytuacja dochodowa państw UE była bardzo zróżnicowana. Wynikało to przede wszystkim z zasobów, którymi dysponowali rolnicy w poszczególnych krajach. Niemniej jednak o wysokości dochodu niekoniecznie musi decydować ziemia, czego przykładem były dane gospodarstw z Malty, wskazujące na bardzo wysokie dochody przy najmniejszej średniej powierzchni UR i jednoczesnym bardzo wysokim wyposażeniu w aktywa. Najwyższe dochody niezależnie od tego czy dopłaty wystąpiły, czy ich by nie było, osiągali rolnicy z Malty, Włoch i Holandii, natomiast najniższe mimo dużego wyposażenia w ziemię - Słowacy. Stwierdzono także, że występuje tendencja spadkowa w poziomie dochodów w niemal wszystkich krajach, z wyjątkiem Włoch, gdzie dochody były stabilne. $Z$ badań wynika także, że w niemal połowie krajów Unii osiągnięcie dochodu rolniczego nie byłoby możliwe, gdyby nie wsparcie i dopłaty do działalności operacyjnej. Największe problemy w tym zakresie miałyby kraje skandynawskie, Słowacja, Czechy oraz Dania.

Na nadwyżkę finansową oddziaływują różne czynniki w zależności od wielkości ekonomicznej. W gospodarstwach słabszych ekonomicznie stymulantami są dochodowość siły roboczej oraz kapitał własny, natomiast w silnych ekonomicznie produkcyjność ziemi i długoterminowe finansowanie zewnętrzne. Natomiast niezależnie od analizowanej grupy destymulantą osiąganej nadwyżki finansowej były dopłaty do działalności operacyjnej, które mogą stanowić zagrożenie utrzymania stabilności finansowej, w sytuacji gdyby wycofano ten instrument wsparcia $\mathrm{w}$ rolnictwie. 
Dopłaty do działalności operacyjnej a stabilność finansowa gospodarstw rolnych...

\section{Bibliografia}

Buks J., Pietrzykowski R. (2015). Relacje między dochodem rolniczym a dopłatami unijnymi w Polsce. Roczniki Naukowe Stowarzyszenie Ekonomistów Rolnictwa i Agrobiznesu, 18 (3), 67-71.

Ciaian P., Swinnen J.F.M. (2009). Credit market imperfections and the distribution of policy rents. American Journal of Agricultural Economics, 91 (4), 124-139.

Crockett A. (1997). Why is financial stability a goal of public policy? Economic Review, 4, $5-22$.

Czubak W., Sadowski A., Poczta W. (2011). Wpływ reformy systemu dopłat bezpośrednich na dochody polskich gospodarstw rolnych z pola obserwacji FADN. W: J. Kulawik (red.). Dopłaty bezpośrednie i dotacje budżetowe a finanse oraz funkcjonowanie gospodarstw i przedsiębiorstw rolniczych (s. 60-79). Program Wieloletni 2011-2014, Raport nr 20. Warszawa: Instytut Ekonomiki Rolnej i Gospodarki Żywnościowej - PIB.

Fidrmuc J., Schardax F. (1999). Increasing integration of applicant countries into international financial markets: Implications for monetary and financial stability. Focus on Transition, 2, 18-46.

Gorczyńska M. (2013). Stabilność finansowa a zrównoważony rozwój przedsiębiorstwa. Zarządzanie i Finanse, 2 (2), 99-110. zif.wzr.pl/pim/2013_2_2_8.pdf [dostęp: 27.07.2017].

Grzelak A. (2012). Sytuacja ekonomiczna w rolnictwie na tle tendencji ogólnogospodarczych w Polsce w latach 1995-2010. Roczniki Naukowe Stowarzyszenia Ekonomistów Rolnictwa i Agrobiznesu, 14 (3), 104-109.

Hennessy D.A. (1998). The production effects of agricultural income support polices under uncertainty. American Journal of Agricultural Economics, 80 (1), 46-57.

Jabłoński A. (2015). Stabilność finansowa przedsiębiorstwa a jego model biznesu. Zeszyty Naukowe Uniwersytetu Przyrodniczo-Humanistycznego w Siedlcach, Seria: Administracja i Zarzadzanie, 104, 87-96.

Jóźwiak W., Mirkowska Z. (2008). Polskie gospodarstwa rolne w pierwszych latach członkostwa. Zagadnienia Ekonomiki Rolnej, 2, 19-32. https:/depot.ceon.pl/bitstream/ handle/123456789/.../Józwiak \%20Mirkowska.pdf [dostęp: 25.09.2017].

Korol J., Szczuciński P. (2012). Ekonometryczne modelowanie zróżnicowania związków w sektorze małych i średnich przedsiębiorstw w przestrzeni regionalnej. Zeszyty Naukowe Uniwersytetu Szczecińskiego, Studia i Prace Wydziału Nauk Ekonomicznych i Zarzadzania (Metody Ilościowe w Ekonomii), 26, 209-224.

Latruffe L., Bravo Ureta B., Moreira V.H., Desjeux Y., Dupraz P. (2011). Productivity and subsidies in European Union countries: An analysis for dairy farms using input distance frontiers. Paper prepared for presentation at the EAAE 2011 Congress, August 30 to September 2, 2011, ETH Zürich, Zürich, Switzerland. http://purl.umn.edu/114396 [dostęp: 24.07.2017].

Marks-Bielska R., Babuchowska K. (2009). Wsparcie dochodów rolników w formie dopłat bezpośrednich. Zeszyty Naukowe SGGW w Warszawie. Ekonomika i Organizacja Gospodarki Żywnościowej, 75, 135-148. 
Mary S. (2012). Assessing the impacts of pillar 1 and 2 subsidies on TFP in French crop farms. Journal of Agricultural Economics, 64 (1), 133-144. http://onlinelibrary.wiley. com/doi/10.1111/j.1477-9552.2012.00365.x/full [dostęp: 24.07.2017].

Mrówczyńska-Kamińska A. (2008). Znaczenie rolnictwa w gospodarce narodowej w Polsce, analiza makroekonomiczna i regionalna. Zeszyty Naukowe SGGW warszawie. Problemy Rolnictwa Światowego, 5 (20), 96-107.

Poczta W. (2008). Rolnictwo. W: I. Nurzyńska, J. Wilkin (red.). Polska wieś 2008: Raport o stanie wsi (s. 27-45). Warszawa: FDPA.

Poczta W., Śledzińska J., Mrówczyńska-Kamińska A. (2009). Determinanty dochodów gospodarstw rolnych Unii Europejskiej według typów rolniczych. Warszawa: Szkoła Główna Gospodarstwa Wiejskiego.

Rizov M., Pokrivcak J., Ciaian P. (2013). CAP subsidies and the productivity of EU farms: Factor markets. Working Paper No. 37, March 2013. https://ssrn.com/abstract=2275273 [dostęp: 24.07.2017].

Ryś-Jurek R. (2009). The output, incomes and assets-capital relations in the individual farms. Journal of Agribusiness and Rural Development, 1 (11), 177-188.

Slavkovský P. (2005). Społeczne i kulturowe konteksty rozwoju rolnictwa słowackiego w XX wieku. Infrastruktura i Ekologia Terenów Wiejskich, 1, 121-131.

Smędzik-Ambroży K. (2015). Wpływ dopłat bezpośrednich na zrównoważenie gospodarstw rolnych w Polsce - próba symulacji na przykładzie gospodarstw FADN z regionu Wielkopolska i Śląsk. Progress in Economic Sciences, 2, 107-117.

Soliwoda M. (2016). The impact of the support instruments of the Common Agricultural Policy on economic and financial stability of farms in EU countries. Acta Universitatis Lodziensis, Folia Oeconomica, 2 (319), 99-116.

Wąs A. (2004). Znaczenie dopłat bezpośrednich i płatności ONW w kształtowaniu wyników finansowych w warunkach różnych scenariuszy rynkowych i wariantów organizacji gospodarstw rolniczych. Roczniki Nauk Rolniczych, Seria G, 91 (2), 16-27.

Zawojska A. (1997). Zróżnicowanie dochodów w gospodarstwach rolniczych w wybranych krajach Unii Europejskiej: Streszczenie rozprawy doktorskiej. Zagadnienia Ekonomiki Rolnej, 2-3, 110-113.

Zhu X., Lansink A.O. (2010). Impact of CAP subsidies on technical efficiency of crop farms in Germany, the Netherlands and Sweden. Journal of Agricultural Economics, 61 (3), 545-564.

Zygierewicz M. (2013). Stabilność finansowa. Annales Universitatis Mariae Curie-Skłodowska. Sectio H, Oeconomia, 47 (3), 685-695. 


\title{
Operational Subsidies and Financial Stability of Farms in the European Union
}

\begin{abstract}
The purpose of the article was to identify financial situation if farms operating in the European Union Member States, account taken of operating subsidies, as well as factors that influenced the financial surplus (cash flow in operating activities). The ability to earn a positive financial surplus was recognized as a manifestation of a farm's financial stability. The data was sourced from FADN database and the research period covered the years 2009-2015. The quartile method was used for grouping Member States; economic size of a farm was the variable used for the classification of a farm to a relevant quartile. Econometric models have been used for panel models with fixed effects. The research showed that farms operating in the European Union differed in terms of production factors, especially land and capital, which was reflected in the achieved economic and financial results. Direct subsidies have been an important element of income over the years in almost all the Member States. Without subsidies, almost half of the EU farmers would not be able to generate any income from farming. The models constructed indicated that the amount of financial surplus was influenced by various factors depending on the economic size of a farm. Regardless of the quartile, the direct subsidies were the inhibitor of financial surplus.
\end{abstract}

Keywords: subsidies, agricultural income, financial surplus, financial stability. 